\title{
IAMJ
}

INTERNATIONAL

AYURVEDIC

MEDICAL JOURNAL

[ब] (1)

Review Article

ISSN: 2320-5091

Impact Factor: 6.719

\section{MANAGEMENT OF CHRONIC OBSTRUCTIVE PULMONARY DISEASE THROUGH AYURVEDA AND YOGA - A REVIEW}

\author{
$\underline{\text { Falguni Joshi }}{ }^{1}$, Ravi Sharma ${ }^{2}$, Mahesh Dixit ${ }^{3}$ \\ ${ }^{1}$ PG Scholar, ${ }^{2}$ Prof. \& H.O.D., ${ }^{3}$ Prof. Principal. \\ Department of Kaya Chikitsa, MMM Govt. Ayurved College, Udaipur, Rajasthan, India
}

Corresponding Author: hinadosi67@gmail.com

https://doi.org/10.46607/iamj10p5032021

(Published online: March 2021)

Open Access

(C) International Ayurvedic Medical Journal, India 2021

Article Received: 09/03/2021 - Peer Reviewed: 11/03/2021 - Accepted for Publication: 15/03/2021

Check for updates

\section{ABSTRACT}

Chronic Obstructive Pulmonary Disease (COPD) which includes chronic bronchitis and emphysema, is the third leading cause of death and over the last 20 years, its prevalence has gradually increased. The key explanation may be rapid socio-economic growth, resulting in a transition from traditional to modern lifestyles. From Ayurveda point of view, COPD can be compared with Pranavaha Srotas disease, as the etiological factors and clinical characteristics mentioned in Ayurvedic classics for Pranavaha Srotodushti are almost identical to those for COPD and usually occur in Tamaka Shwasa. Risk factors include exposure to air pollution, second-hand smoke and occupational dusts and chemicals, smoking, cold weather etc. which are also mentioned in Ayurvedic classics "Rajasa Dhoomvatabhyam Shitathanambusevanam Rukshanna Vishmashana". Identification, reduction, and control of risk factors to prevent the onset of COPD are important steps towards developing strategies for prevention of COPD. References regarding lifestyle modification along with treatment principle \& formulations mentioned in Ayurveda can be adopted for the prevention and management of COPD.

Keywords: COPD, Yogic procedures, Tamaka Shwasa, Pranavaha Srotasa

\section{INTRODUCTION}

Chronic obstructive pulmonary disease is an important health challenge among population $\&$ it is a major cause of morbidity and mortality throughout the world.
It is defined as a disease state characterised by airflow obstruction. COPD includes emphysema, chronic bronchitis. In COPD, pulmonary symptoms include - 
dyspnoea, cough whereas extrapulmonary manifestations include weight loss \& skeletal muscle dysfunction. COPD is a common preventable $\&$ treatable disease, is characterised by persistent airflow limitations that is usually progressive and associated with an enhanced inflammatory response in the airways and the lungs to noxious particles and gases. ${ }^{1}$

COPD is currently the third leading cause of death in the world. More than 65 million people suffers from COPD in 2019. Globally, the COPD burden is projected to increase in coming decades because of continued exposure to COPD risk factors and aging of the population.

In Ayurveda all the respiratory disorders are due to abnormality in Pranavaha Srotas. COPD can be corelated with 'Tamaka Shwasa' in Ayurveda. In Tamaka Shwasa the patient suffers from respiratory disorders like difficulty in breathing, cough etc.

\section{DISCUSSION}

Aetiopathogenesis- The prevalence of COPD is related to prevalence of tobacco smoking and in low- and middle-income groups, exposure to biomass fuel. Secondhand smoking (exposure to environmental tobacco smoke), exposure to fumes and smoke from carbon-based cooking \& heating fuels ex. Charcoal and gas, occupational hazards like chemical, dust are also the risk factors for COPD.

Alpha-1 antitrypsin deficiency and childhood respiratory infections also plays a major role.

Poor nutrition affects pulmonary function \& increase the risk of exacerbation.In the developing countries, the most important risk factor for COPD could be indoorair pollution arising from the use of biomass fuel, such as wood, cow dung and crop-residues leads to release of air pollutants like $\mathrm{SO}_{2}, \mathrm{CO}, \mathrm{NO}_{2}$, formaldehyde and particulate matters smaller than 10 micron in size in the ambient indoor air.

Tuberculosis is increasingly getting recognized as a risk factor for COPD. Physiological lung function decline induced by ageing can also predispose to COPD. In Ayurveda the risk factors for COPD are mentioned as following -
"Rajasa Dhoomvatabhyam Shitathanambusevanam Rukshanna Vishmashana (ch.chi.17/13

Tamaka Shwas etiology-

COPD is due to toxic substance inhalation. Which cause inflammatory condition in lungs. Due to defective repairing mechanism of lungs, inflammation leads to tissue damage. This results in hypersecretion of mucous, airway narrowing \& fibrosis, vascular changes \& destruction of parenchyma. Due to this, pathological abnormalities occur as the manifestations of COPD. In Ayurveda, the Samprapti of Pranavaha Srotas is mentioned as-

Indulgence in etiological factors, vitiated Prana and Udana located in Pranavaha Srotas enforces

Kapha, ensuing into obstruction of channels of Pranavaha.

\section{Clinical features-}

COPD should be suspected in any patient over the age of 40 years with persistent cough \& sputum and /or breathlessness associated with an enhanced chronic inflammatory response to noxious particles or gases. In advance disease there may be edema or morning headache. Two classical phenotypes have been described Pink Puffers (thin \& breathless, maintain a normal PaCo2, Blue Bloaters (develop morning headache, edema \& secondary polycythaemia). ${ }^{4}$

In Ayurveda, the manifestations of the vitiation of Pranavaha

Srotasa are described in Charak Samhita:

Atisritam Atibaddhama (too long or too restricted respiration), Kupita (Respiration pattern disturbed) Alpa-Alpam (shallow or frequent respiration), Sashoolam-Sashabdam (respiration with pain \& sound). ${ }^{5}$

\section{Investigations $\mathbf{6}^{\mathbf{-}}$}

Chest X-Ray, Alpha-antitrypsin level, carbon mono oxide transfer factor, CT Scan, Spirometry. Spirometry is used to classify disease severity. In spirometry 4 stages are consideredas basis for diagnosis of COPD.

Stage 1 - FEV1 $>80 \%$, FEV1/FVC $<0.7$

Stage 2 - FEV1 50-79\%, FEV1/FVC $<0.7$

Stage 3 - FEV1 30-49\%, FEV1/FVC $<0.7$

Stage 4-FEV $1<30 \%$, FEV1/FVC $<0.7$

\section{Management-}


According to modern science, bronchodilators, anti- inflammatory drugs, antibiotics, mucolytics, oral glucocorticoids are given in COPD. Other treatments are pulmonary rehabilitation, oxygen therapy, ventilatory support, lung volume reduction surgery. ${ }^{7}$

In Ayurveda, for prevention or management of any disease there are three main steps-

\section{Nidanparivarjan}

2. Shodhanchikitsa

3. Shamanchikitsa

By thinking about these 3 steps, the management of COPD have to be done. In Nidanparivarjan patient desires to keep away from the reason elements like smoking have to be stopped, take suitable precautions in occupational environment. Avoid touch with immoderate heat, cold, irritants. Avoid day sleep. By Shodhanchikitsa, extra kaphadosha will alleviate and it's going to dry extra mucous secretions in pranavahastrotas. Shodhanchikitsa include Vamana (therapeutic emesis), Virechana (therapeutic purgation), Basti (therapeutic enema). In Shwasa Roga, Shodhan chikitsa should apply on Balwan Rogi.It depends on Ritu \& Kala. According to Acharya Charak "Tamake tu Virechanam" ${ }^{\prime \prime}$ means there is special indication of Virechana Karma in Tamaka Shwas. By Virechana, the gati of Vata become downwards hence it will remove the obstruction, which is caused by Pratiloma Gati of Vata. In Shamana chikitsa, following medications are described in Ayurvedic texts, Shatyadi Churna, Muktadi Churna, Tejovatyadi Ghrita, Manahashiladi Ghrita, Bharangi-NagarYoga, Sitopaladi Churna, Vyaghri Haritaki Avaleha, Chitraka Haritaki Avaleha. These drugs can alleviate the vitiated Kapha and may dry out excess mucous secretions in the Pranavaha Srotasa.

\section{Pathya-Apathya in the management of COPD}

For whole alleviation from COPD, medicines aren't enough. We have to additionally attention on food regimen \& lifestyle. It can facilitate to prevent COPD. In Ayurveda there is much more emphasize on diet regimen than medications. The Aahar-Vihar which is beneficial \& nutritional to the body and also gives happiness to the mind is known as Pathya \& opposite to that is known as Apathya . In Charak Samhita, any drug which is Kapha- Vatanashamak, Ushna \& Vatanulomaka, can be used in Shwasa as Aushadh, Aahar\&Vihar. Following Aahar-Vihar are considered as Pathya in Shwasa Roga-

Aahar- Purana Shalichawal, Purana Shashtika, Purana Godhum \& Yava, Mudaga, Kulattha, Ushan Jala, Purana Goghrita, Gomutra, Jivanti, Choti Ala, Harad, Trikatu, Lahsuna (Garlic), Bimbi (Ivy gourd), Draksha (Raisins) $^{10}$

Vihar-Vamana (therapeutic emesis), Virechana (therapeutic purgation), Basti (therapeutic enema), Swedana (Sudation), Dhumapana (Herbal Smoking), Diwaswapna (Sleeping during the daytime), Daha Karma.

Following Aahar-Vihar are considered as Apathya in Shwasa Roga-

Aahar-Ruksha Anna, Vishma Ashana, Kapha vardhak Aahar, Jalajmans, Anupamans, Semafali, TilTail, Kamalkand, Dahi, Dugdh ${ }^{10}$.

Vihar-Atimethun, Ativyayam, Sheetal Sthan, Sheetal Jal Sevan, Ativaman, Ativirechan, Meghambu, PurviVatasevan. ${ }^{10}$

\section{Yoga procedure in the management of COPD-}

Yoga plays a major role in the management of COPD. Yoga either by physical posters (Asanas) or by breathing techniques (Pranayama) are useful in the patient of COPD. Pranayama purifies Nadi. By practice of Pranayama, patient got relief from breathlessness. Pranayama helps in strengthening the respiratory muscles. It has been reported that Pranayama and meditation give patients control over their autonomic functions and allow them to relax and develop their motor skills when asthma begins. It can also help patients with additional respiratory disorders, such as chronic bronchitis.

Practice of Yoga improves various vital organs and increases their functional capacities. Bhujangasana, Savasana, Shalabhasana and Paschimotasana apply Asana to Pranavaha Srotas as they improve blood circulation in the lungs and increase endurance. ${ }^{11}$

\section{CONCLUSION}

COPD being a chronic progressive disease with irreversible changes needs early diagnosis and proper 
management. An extra care of diet, diet- pattern modifications and life style modifications can play a major role in prevention of COPD.

\section{REFERENCES}

1. Davidson's principle \& practice of medicine, 21st edition, Churchill livingstone Elsevier 2010, pg280.

2. Charak Samhita of Agnivesha Revised by Charaka and Drihabala with elaborated Vidyotini Hindi commentary by Pandit Kashinath Sastriand Dr. Gorakha Natha Chaturvedi. ChikitsaSthan, 17/13

3. CharakSamhita of Agnivesha Revised by Charaka and Drihabala with elaborated Vidyotini Hindi commentary by Pandit Kashinath Sastriand Dr. Gorakha Natha Chaturvedi. ChikitsaSthan, pg526

4. Davidson's principle \& practice of medicine, 21st edition, Churchill livingstone Elsevier 2010, pg282

5. CharakSamhita of Agnivesha Revised by Charaka and Drihabala with elaborated Vidyotini Hindi commentary by Pandit Kashinath Sastriand Dr. Gorakha Natha Chaturvedi. Vimana Sthana, 5/7, pg710

6. Davidson's principle \& practice of medicine, $21 \mathrm{st}$ edition, Churchill livingstone Elsevier 2010, pg282

7. Davidson's principle \& practice of medicine, 21 st edition, Churchill livingstone Elsevier 2010, pg283

8. CharakSamhita of Agnivesha Revised by Charaka and Drihabala with elaborated Vidyotini Hindi commentary by PanditKashinathSastriandDr.GorakhaNathaChaturvedi. ChikitsaSthan, 17/121

9. CharakSamhita of Agnivesha Revised by Charaka and Drihabala with elaborated Vidyotini Hindi commentary by PanditKashinathSastriandDr.GorakhaNathaChaturvedi. SutraSthan,25/45

10. Bhaishajya Ratnavalikavirajambikadata shastri rachit 16/132-139

11. The yoga and holistic health, Dr. Amarjeet, Literary circle, Jaipur-2012.

\section{Source of Support: Nil}

\section{Conflict of Interest: None Declared}

How to cite this URL: Falguni Joshi et al: Management Of Chronic Obstructive Pulmonary Disease Through Ayurveda And Yoga - A Review. International Ayurvedic Medical Journal \{online\} 2021 \{cited March, 2021\} Available from: http://www.iamj.in/posts/images/upload/2826_2829.pdf 